\title{
Spiroplasma platyhelix sp. nov., a New Mollicute with Unusual Morphology and Genome Size from the Dragonfly Pachydiplax longipennis
}

\author{
DAVID L. WILLIAMSON,${ }^{1 *}$ JEAN R. ADAMS, ${ }^{2}$ ROBERT F. WHITCOMB, ${ }^{3}$ JOSEPH G. TULLY,
} PATRICIA CARLE, ${ }^{5}$ MEGHNAD KONAI, ${ }^{2} \dagger$ JOSEPH M. BOVÉ, ${ }^{5}$ AND ROBERTA B. HENEGAR ${ }^{3}$

\begin{abstract}
Department of Anatomical Sciences, State University of New York, Stony Brook, New York 11794 ${ }^{1}$; Insect Biocontrol Laboratory, ${ }^{2}$ and Vegetable Laboratory, ${ }^{3}$ U. S. Department of Agriculture, Beltsville, Maryland 20705; Mycoplasma Section, Laboratory of Molecular Microbiology, National Institute of Allergy and Infectious Diseases, Frederick Cancer

Research Facility, Frederick, Maryland 217024; and Laboratoire de Biologie Cellulaire et Moléculaire, Institute Nationale de la Recherche Agronomique and Université de Bordeaux II, 33883 Villenave d'Ornon, France ${ }^{5}$
\end{abstract}

\begin{abstract}
Spiroplasma strain PALS-1 ${ }^{\mathrm{T}}$ from the gut of the dragonfly Pachydiplax longipennis was shown to be distinct from other species, groups, and subgroups of the genus Spiroplasma as determined by reciprocal serological metabolism inhibition and deformation tests. However, this strain cross-reacted extensively with representatives of other groups when it was used as an antigen. Electron microscopy of cells of strain PALS-1 ${ }^{\mathrm{T}}$ revealed cells surrounded by a single cytoplasmic membrane. Light microscopy revealed helical cells that exhibited twisting motility rather than rotatory or flexing motility. Variations in the tightness of coiling were transmitted from one end of the helix to the other. The strain was resistant to penicillin, which confirmed that no cell wall was present. The organism grew well in M1D and SP-4 liquid media under either aerobic or anaerobic conditions. Growth also occurred in $1 \%$ serum fraction medium and in conventional horse serum medium. The optimum temperature for growth was $30^{\circ} \mathrm{C}$, at which the doubling time was $6.4 \mathrm{~h}$. Multiplication occurred at temperatures from 10 to $32^{\circ} \mathrm{C}$. Strain PALS-1 ${ }^{\mathrm{T}}$ catabolized glucose and hydrolyzed arginine but not urea. The guanine-plus-cytosine content of the DNA was $29 \pm 1 \mathrm{~mol} \%$. The genome size was $780 \mathrm{kbp}$, the smallest genome size in the genus Spiroplasma. Strain PALS-1 (= ATCC 51748) is designated the type strain of a new species, Spiroplasma platyhelix.
\end{abstract}

The genus Spiroplasma $(18,26)$ is a large, possibly immense genus of arthropod-associated helical wall-less procaryotes $(8$, 9). Most of these organisms are associated primarily with insects, in a variety of cycles $(5-7,9)$. In 1980, a group classification system was proposed for the genus Spiroplasma (11); later, criteria for recognition of groups were proposed (23). The number of recognized Spiroplasma groups recently increased from 25 to 34 as a result of descriptions of eight new strains of insect-related spiroplasmas $(20,23,28)$. The majority of spiroplasma strains have been isolated from recent orders of insects (Paraneoptera [hemipterous insects] and Holometabola [insects with complete metamorphosis]), and a representative of only one primitive order (Odonata) has been found to carry a spiroplasma strain (8). This strain, designated PALS- $1^{\mathrm{T}}$, was obtained from a dragonfly, Pachydiplax longipennis (Odonata: Libellulidae). In this paper, we present the results of a taxonomic study of strain PALS $-1^{\mathrm{T}}$, organized on the basis of the proposed (10) minimal requirements for assignment of binomial names to mollicutes. As a result of this study, we designate strain PALS-1 (= ATCC 51748) (group XXVIII) the type strain of a new species, Spiroplasma platyhelix.

\section{MATERIALS AND METHODS}

Spiroplasma strains. The techniques used to isolate strain PALS $-1^{T}$ from its dragonfly host have been described previously $(13,22)$. Strain PALS $-1^{\mathbf{T}}$ was isolated and cultivated from the gut of a $P$. longipennis adult of unknown sex

* Corresponding author. Mailing address: Department of Anatomical Sciences, Health Sciences Center, State University of New York, Stony Brook, NY 11794-8081. Phone: (516) 444-3118. Fax: (516) 4443947. E-mail: DWMSON@EPO.SOM.SUNYSB.EDU.

$\dagger$ Present address: 9125 Tymat Court, Laurel, MD 20723. collected by R. B. Henegar on 14 July 1986 at Log Lodge Pond on the grounds of the Beltsville Agricultural Research Center in Beltsville, Md. Some of the genomic and serological features of the organism have been reported previously (23). Strain PALS-1 ${ }^{\mathrm{T}}$ was purified by conventional filtration-cloning techniques (15). Representative strains of all previously recognized groups and subgroups, including the type strains of recognized species, were employed in our comparative studies (17)

Culture medium and cultivation techniques. The culture from which strain PALS $-1^{\mathrm{T}}$ was derived was grown in primary culture in M1D liquid medium (21) at $30^{\circ} \mathrm{C}$. After several early broth passages, the isolate was cloned (15). A triply cloned strain designated PALS $-1^{\mathrm{T}}$ was used in the characterization studies. Other media employed included SP-4 medium (21), serum fraction broth supplemented with $1 \%$ bovine serum fraction (16), and conventional horse serum medium (21). Solid formulations of these media were prepared by adding Noble agar (Difco Laboratories, Detroit, Mich.) to a final concentration of $2.25 \%$. Agar cultures were incubated at $30^{\circ} \mathrm{C}$ either aerobically with $5 \%$ carbon dioxide (GasPak system; BBL Microbiology Systems, Cockeysville, Md.) or anaerobically (hydrogen GasPak system). Temperature requirements for growth were assessed by the method of Konai et al. (12).

Morphological studies. Cells of strain PALS $-1^{\mathrm{T}}$ in the logarithmic phase were examined by dark-field microscopy at a magnification of $\times 1,250$. For dark-field electronic flash photography, $500 \mu$ l of a mid-logarithmic-phase culture in M1D medium was centrifuged at $12,000 \times g$ for $15 \mathrm{~min}$ at $4^{\circ} \mathrm{C}$. The pellet was resuspended in $100 \mu \mathrm{l}$ of the supernatant, and an equal volume of $3 \%$ glutaraldehyde in M1D medium was added dropwise. After $1 \mathrm{~h}$ of fixation, the suspension was examined and photographed without further treatment. A similar suspension of strain PALS $-1^{\mathrm{T}}$ fixed in $1.5 \%$ (final concentration) glutaraldehyde was prepared and used for electron microscopy of negatively stained specimens (24) Previously described procedures (24) were used for electron microscopic studies of the fine structure of strain PALS- ${ }^{\mathrm{T}}$ cells.

Sterol requirement. Sterol requirements for growth were determined by measuring the protein yields of strain PALS $-1^{\mathrm{T}}$ grown in serum-free broth supplemented with different amounts of cholesterol and by a modified broth culture dilution method $(14,16)$

Tests for biological and biochemical properties. The procedures used to study glucose fermentation and hydrolysis of arginine and urea have been described previously (1). Filtration characteristics were determined in M1D broth by previously described techniques (15).

Serological tests. Antiserum to strain PALS $-1^{\mathrm{T}}$ was produced in rabbits as previously described (25). Hyperimmune antisera to all previously established Spiroplasma species and groups (17) were obtained from the reference collec- 


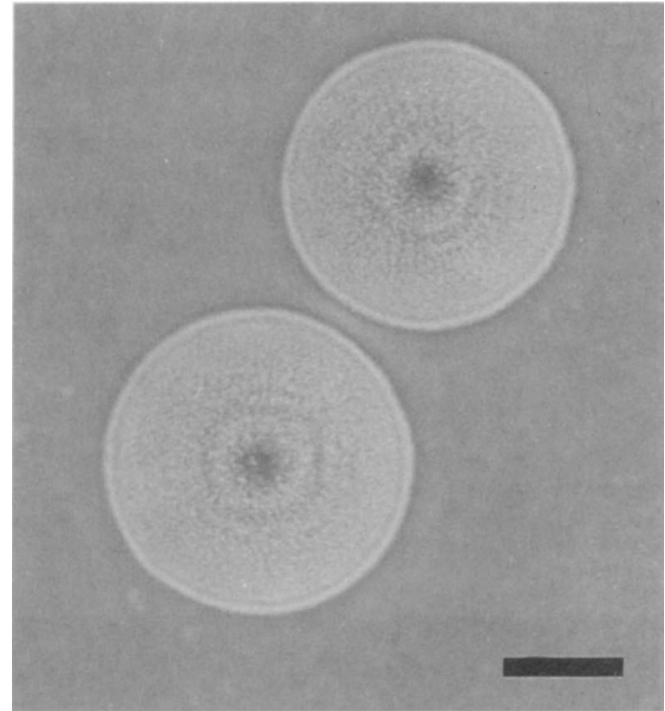

FIG. 1. Colonies of strain PALS- $1^{\mathrm{T}}$ on SP-4 medium supplemented with $2.25 \%$ Noble agar after 7 days of incubation at $30^{\circ} \mathrm{C}$ under aerobic conditions $\mathrm{Bar}=100 \mu \mathrm{m}$.

tions at the Beltsville Agricultural Research Center and the National Institute of Allergy and Infectious Diseases laboratory in Frederick, Md. These antisera and strain PALS $-1^{\mathrm{T}}$ were used in metabolism inhibition and deformation tests as previously described $(25,27)$.

Genomic analysis. The techniques used for extraction and purification of chromosomal DNA from strain PALS-1 ${ }^{\mathrm{T}}$ have been described previously (2) The genome size of strain PALS $-1^{\mathrm{T}}$ was determined as described by Carle et al. (4). The guanine-plus-cytosine content of purified strain PALS-1 ${ }^{\mathrm{T}}$ DNA was determined by the buoyant density and melting temperature methods (3). Purified DNA from Spiroplasma citri (genome size, 1,820 kbp; guanine-plus-cytosine content, $26 \pm 1 \mathrm{~mol} \%$ ) was used as a reference in all procedures (4).

\section{RESULTS AND DISCUSSION}

Cultural and morphological properties. Strain PALS- ${ }^{\mathrm{T}}$ grew well in liquid M1D and SP-4 media and on solid SP-4 medium. The strain also grew in conventional mycoplasma media containing horse serum (Edward formulation) or $1 \%$ bovine serum fraction. Growth occurred at temperatures ranging from 10 to $32^{\circ} \mathrm{C}$; optimum growth was observed at $30^{\circ} \mathrm{C}$, at which the doubling time was $1.9 \mathrm{~h}$. No growth was observed during 3 weeks of incubation in broth media at 5 or $37^{\circ} \mathrm{C}$. Strain PALS $-1^{\mathrm{T}}$ grew on solid medium in agar plates incubated (aerobically) at $30^{\circ} \mathrm{C}$. On $2.25 \%$ agar, strain PALS $-1^{\mathrm{T}}$ formed perfect fried-egg colonies with smooth edges; no satellites were observed (Fig. 1).

As determined by dark-field microscopy, logarithmic-phase cultures of strain PALS-1 ${ }^{\mathrm{T}}$ in M1D medium contained filaments that had barely visible helicity along most of their length and displayed very little rotatory or flexing motility. Organisms not attached to glass moved in a twisting fashion. Figure 2 shows glutaraldehyde-fixed filaments as revealed by dark-field microscopy; these cells displayed the low-pitch helical morphology of strain PALS $-1^{\mathrm{T}}$ spiroplasmas. A fascinating characteristic of these filaments, which is dramatically displayed by living spiroplasmas observed by dark-field microscopy, is the presence of a highly refractile segment (Fig. 2, arrow) that spontaneously appears at one end and moves along the length of each filament to the opposite end, at which point it appears to become unwound. When negatively stained specimens were examined by electron microscopy, this refractile segment was found to be comprised of three or four tightly wound helical

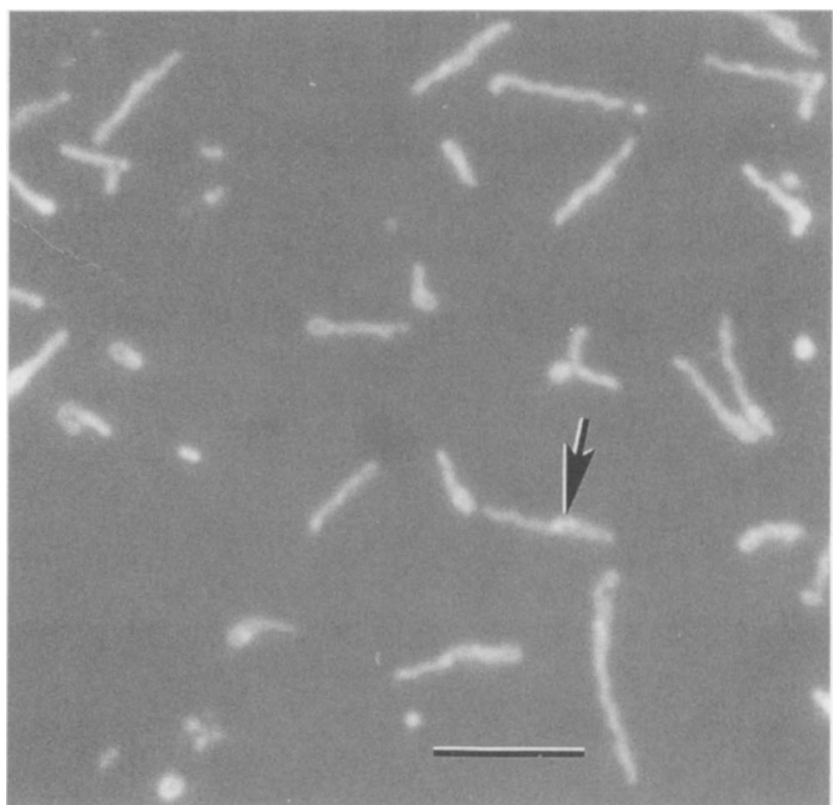

FIG. 2. Dark-field electronic flash photomicrograph of strain PALS-1 ${ }^{\mathrm{T}}$ cells fixed in $1.5 \%$ glutaraldehyde in M1D medium. The arrow indicates the lightrefractive segment of tightly wound helices that travels along the length of the living cell. Bar $=5 \mu \mathrm{m}$.

turns (Fig. 3). Electron microscopy of thin sections of PALS $-1^{\mathrm{T}}$ cells embedded in plastic revealed that the cells possess a typical trilaminar membrane (Fig. 4). Figure 4 also shows that some cells contain viruslike particles in their cytoplasm.

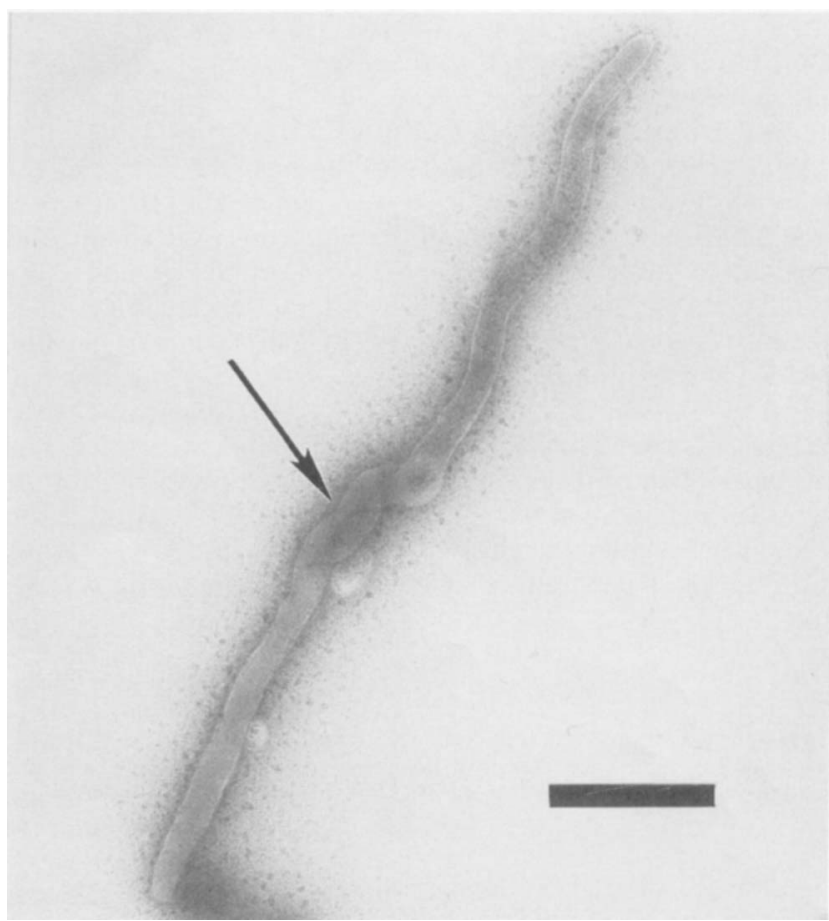

FIG. 3. Electron micrograph of a strain PALS- $1^{\mathrm{T}}$ cell fixed in $1.5 \%$ glutaraldehyde in M1D medium and negatively stained with $1 \%$ phosphotungstic acid $(\mathrm{pH}$ 7.4). The arrow indicates a segment of tightly wound helices. Bar $=1 \mu \mathrm{m}$ 


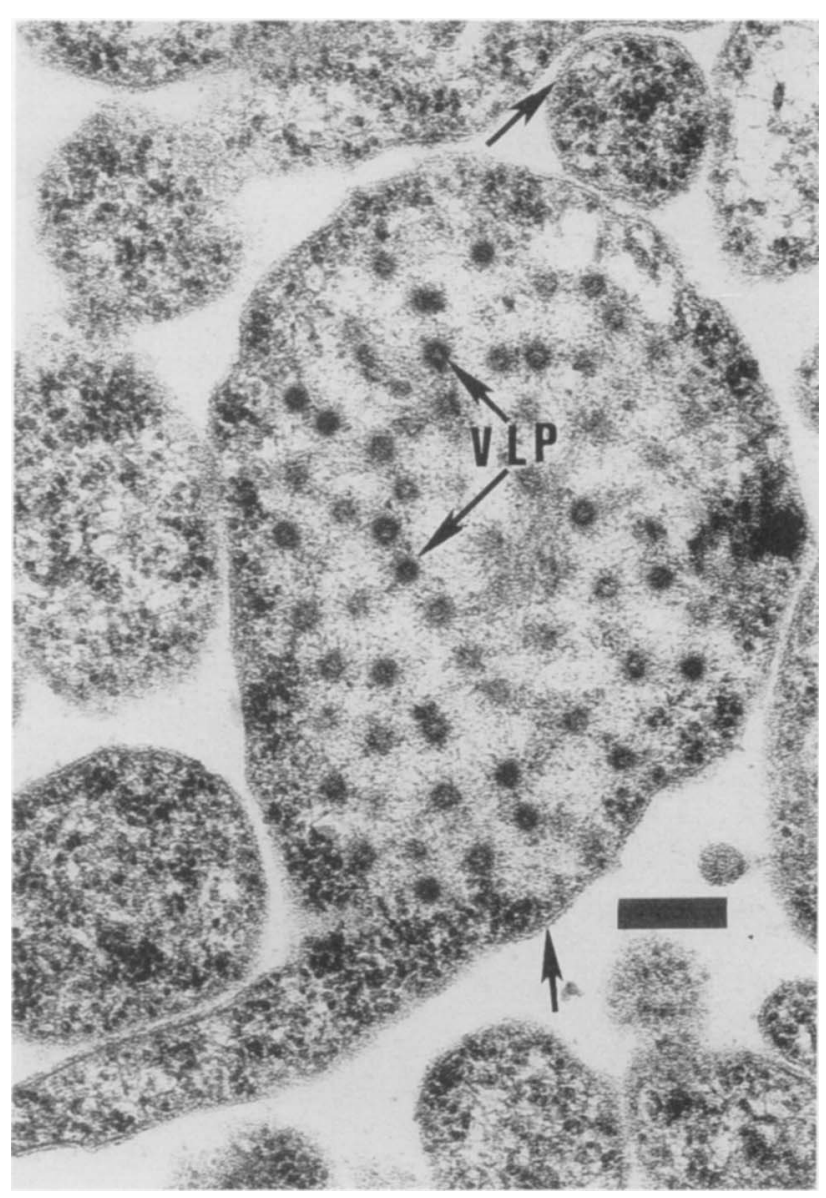

FIG. 4. Electron micrograph of a sectioned and stained pellet of strain PALS $-1^{\mathrm{T}}$ cells. The section was stained with $2 \%$ aqueous uranyl acetate and Reynold's lead citrate. The unlabeled arrows indicate the unit membrane. Intracellular viruslike particles (VLP) in a bulbous portion of one cell are indicated by arrows. Bar $=200 \mathrm{~nm}$.

Sterol requirement. The response of strain PALS-1 ${ }^{\mathrm{T}}$ to cholesterol supplementation of serum-free SP-4 medium is shown in Table 1. No growth was apparent in base broth alone, but growth was enhanced when 5 or $10 \mu \mathrm{g}$ of cholesterol per ml was included. Lower concentrations of cholesterol did not stimulate growth, and $20 \mu \mathrm{g} / \mathrm{ml}$ was inhibitory. As determined by the modified serial dilution method (data not shown), strain PALS $-1^{\mathrm{T}}$ grew through 23 passages in medium containing fetal bovine serum, but did not grow beyond a single 10 -fold dilution in serum-free medium or serum-free medium supplemented

TABLE 1. Growth response of strain PALS-1 $1^{\mathrm{T}}$ to cholesterol

\begin{tabular}{lcc}
\hline \multicolumn{1}{c}{ Medium } & $\begin{array}{c}\text { Cholesterol concn } \\
(\mu \mathrm{g} / \mathrm{ml})\end{array}$ & $\begin{array}{c}\text { Amt of protein } \\
(\mathrm{mg} / 100 \mathrm{ml})\end{array}$ \\
\hline M1D (control) & & 0.63 \\
Serum fraction (control) & & 0.51 \\
Serum free & 0 & $\mathrm{IG}^{a}$ \\
& 1 & $\mathrm{IG}$ \\
& 2 & $\mathrm{IG}$ \\
& 5 & 3.04 \\
& 10 & 3.10 \\
& 20 & 0.03 \\
\hline
\end{tabular}

${ }^{a}$ IG, insufficient growth.
TABLE 2. Serological reactions and cross-reactions of strain PALS-1 ${ }^{\mathrm{T}}$

\begin{tabular}{|c|c|c|c|c|c|}
\hline \multirow{3}{*}{ Group } & \multirow{3}{*}{ Strain } & \multicolumn{4}{|c|}{ Titer in: } \\
\hline & & \multicolumn{2}{|c|}{$\begin{array}{c}\text { Spiroplasma } \\
\text { deformation test }\end{array}$} & \multicolumn{2}{|r|}{$\begin{array}{l}\text { Metabolism } \\
\text { inhibition test }\end{array}$} \\
\hline & & $\begin{array}{l}\text { Anti- } \\
\text { serum }\end{array}$ & Antigen & $\begin{array}{l}\text { Anti- } \\
\text { serum }\end{array}$ & Antigen \\
\hline $\mathrm{I}-3$ & $\mathrm{E} 275^{\mathrm{T}}$ & $0^{a}$ & $20(20,480)^{b}$ & $0^{c}$ & $486(>117,000)^{b}$ \\
\hline III & $23-6^{\mathrm{T}}$ & 0 & $20(10,240)$ & 0 & $0(39,000)$ \\
\hline VII & MQ-1 ${ }^{\mathrm{T}}$ & 40 & $0(1,240)$ & 0 & $0(117,000)$ \\
\hline VIII-3 & TAAS-1 & 0 & $0(2,560)$ & 0 & $54(39,000)$ \\
\hline XII & DU-1 ${ }^{\mathrm{T}}$ & 0 & $0(5,120)$ & 0 & $54(13,000)$ \\
\hline XVI-2 & CB-1 & 0 & $0(2,560)$ & 0 & $54(39,000)$ \\
\hline XVI-3 & Ar 1357 & 0 & $0(20,480)$ & 0 & $18(117,000)$ \\
\hline XVIII & $\mathrm{TN}-1^{\mathrm{T}}$ & 40 & $0(2,560)$ & 0 & $486(>117,000)$ \\
\hline XIX & PUP-1 $^{\mathrm{T}}$ & 0 & $0(10,240)$ & 54 & $0(>117,000)$ \\
\hline $\mathrm{XX}$ & LD-1 ${ }^{\mathrm{T}}$ & 0 & $40(20,480)$ & 162 & $1,458(117,000)$ \\
\hline XXI & W115 & 0 & $0(40,960)$ & 0 & $54(13,000)$ \\
\hline XXIV & $\mathrm{CCH}^{\mathrm{T}}$ & 0 & $0(640)$ & 0 & $18(39,000)$ \\
\hline $\mathrm{XXV}$ & CUAS-1 ${ }^{\mathrm{T}}$ & 80 & $40(640)$ & 0 & $18(13,000)$ \\
\hline XXVI & PLHS-1 $^{\mathrm{T}}$ & 0 & $0(2,560)$ & 162 & $54(117,000)$ \\
\hline XXVIII & PALS-1 ${ }^{\mathrm{T}}$ & $1,280^{d}$ & $1,280^{d}$ & $4,374^{d}$ & $4,374^{d}$ \\
\hline XXX & BIUS-1 & 0 & $0(10,240)$ & 0 & $486(39,000)$ \\
\hline XXXII & TABS-2 ${ }^{\mathrm{T}}$ & 0 & $0(640)$ & 0 & $54(39,000)$ \\
\hline \multirow[t]{2}{*}{ XXXIII } & TAUS-1 ${ }^{\mathrm{T}}$ & 0 & $0(5,120)$ & 0 & $54(39,000)$ \\
\hline & All others & 0 & 0 & 0 & 0 \\
\hline
\end{tabular}

${ }^{a}$ Reciprocal of the endpoint in the deformation test in which the antigen was tested with the homologous antiserum.

${ }^{b}$ Homologous titer of the antiserum against which strain PALS- ${ }^{\mathrm{T}}$ crossreacted when it was used as the antigen in heterologous tests.

Reciprocal of the endpoint in the metabolism inhibition test in which the antigen was tested with the homologous antiserum.

${ }^{d}$ Homologous titer of strain PALS- $1^{\mathrm{T}}$ in the test system. The reaction, obtained once, is included for completeness.

with $0.04 \%$ Tween 80 . The strain therefore requires serum or cholesterol $(14,16)$.

Biochemical and biological properties. Strain PALS- $1^{\mathrm{T}}$ produced acid from glucose and hydrolyzed arginine but not urea. Passage of broth cultures of strain PALS-1 ${ }^{\mathrm{T}}$ through $450-\mathrm{nm}$ pore-size membrane filters reduced the viable cell titer from $10^{9}$ to $10^{8}$ color-changing units $/ \mathrm{ml}$. The titer of a broth culture filtrate obtained after passage through a 300 -nm-pore-size membrane filter was also reduced about 10 -fold (to $10^{7}$ colorchanging units $/ \mathrm{ml}$ ). Passage through $220-\mathrm{nm}$ filter pores reduced the titer by $3 \log _{10}$ units. The 100 -nm-pore-size membrane filtrate did not contain viable cells.

Serological tests. The results of metabolism inhibition and spiroplasma deformation tests (Table 2) indicated that strain PALS $-1^{\mathrm{T}}$ was not related serologically to representatives of previously established groups or species of the genus Spiroplasma. However, when this strain was used as an antigen, it exhibited a broad pattern of one-way cross-reactions in both metabolism inhibition and deformation tests, although some reciprocal cross-reactions did occur. For example, Table 2 shows the reciprocal metabolism inhibition test titers involving strains LD- $1^{\mathrm{T}}$ (group XX, Spiroplasma leptinotarsa) and PLHS$1^{\mathrm{T}}$ (group XXVI) and the reciprocal deformation test titers for strain CUAS-1 ${ }^{\mathrm{T}}$ (group $\mathrm{XXV}$, Spiroplasma diminutum). It should be noted that in each of these examples, the reciprocal cross-reactions occurred in either the deformation test or the metabolism inhibition test, but not in both.

Genome size and DNA base composition. The size of the undigested linear DNA of strain PALS-1 ${ }^{\mathrm{T}}$ was $780 \mathrm{kbp}$ as determined by pulsed-field gel electrophoresis and $770 \mathrm{kbp}$ as determined from the sum of the sizes of restriction fragments 
after SstII digestion (1a). The base composition (guanine-pluscytosine content) of PALS-1 ${ }^{\mathrm{T}}$ DNA was $29 \pm 1 \mathrm{~mol} \%$. Thus, the genome size of strain PALS- ${ }^{\mathbf{T}}$ is by far the smallest genome size in the genus Spiroplasma. The genome size and guanine-plus-cytosine content of strain PALS $-1^{\mathrm{T}}$ clearly distinguish this organism from the three strains with which it exhibited serological reciprocal cross-reactions, strains LD- ${ }^{\mathrm{T}}$ (genome size, 1,085 kbp; guanine-plus-cytosine content, $25 \pm 1$ mol\%), PLHS-1 ${ }^{\mathrm{T}}$ (genome size, $1,465 \mathrm{kbp}$; guanine-plus-cytosine content, $31 \pm 1 \mathrm{~mol} \%$ ), and CUAS- $1^{\mathrm{T}}$ (genome size, 1,080 $\mathrm{kbp}$; guanine-plus-cytosine content, $26 \pm 1 \mathrm{~mol} \%$ ).

Habitat. Strain PALS $-1^{\mathrm{T}}$ is not known to be pathogenic for insects. The single strain described here was isolated directly from the gut of a dragonfly ( $P$. longipennis) collected in Beltsville, Md. Members of the insect order Odonata (dragonflies and damselflies) are predatory on other insects, and thus the spiroplasmas in the gut of the specimen collected at Log Lodge Pond may simply have been passively acquired from one of its recent repasts.

The properties described here for strain PALS- $1^{\mathrm{T}}$ fulfill proposed criteria (10) for species of the class Mollicutes, including the absence of a cell wall, filterability, the lack of reversion to walled bacteria when the organism is grown in antibiotic-free media, and penicillin resistance. The helicity and motility of strain PALS $-1^{\mathrm{T}}$ and its inability to utilize urea place this organism in the family Spiroplasmataceae (19). Finally, the results of the serological comparison of strain PALS $-1^{\mathrm{T}}$ with other Spiroplasma species demonstrate the uniqueness of this new insect strain. We therefore propose the name Spiroplasma platyhelix for this organism. The taxonomic description below summarizes the properties of the new species.

Description of Spiroplasma platyhelix sp. nov. Spiroplasma platyhelix (plat.y.he'lix. Gr. adj. platys, flat; Gr. n. helix, a coil or spiral; M. L. fem. n. platyhelix, flat coil, referring to the flattened nature of the helical filament). Cells are flattened, helical, motile filaments that vary from 200 to $300 \mathrm{~nm}$ in diameter. The cells lack true cell walls. Cells plated on SP-4 solid medium containing $2.25 \%$ Noble agar form perfect fried-egg colonies with dense centers and smooth edges and without satellites.

Chemoorganotroph. Acid is produced from glucose. Hydrolyzes arginine but not urea.

Cholesterol or serum is required for growth.

The temperature range for growth is 10 to $32^{\circ} \mathrm{C}$, and optimum growth occurs at $30^{\circ} \mathrm{C}$. The doubling time at the optimum temperature in M1D medium is $6.4 \mathrm{~h}$.

Serologically distinct from other established Spiroplasma species. Isolated from the gut of the dragonfly $P$. longipennis. Pathogenicity for insects has not been determined.

The guanine-plus-cytosine content of the DNA is $29 \pm 1$ mol $\%$, as determined by the buoyant density method. The genome size is $780 \mathrm{kbp}$.

The type strain is PALS-1 (= ATCC 51748).

\section{ACKNOWLEDGMENT}

We sincerely appreciate the help of Mark Aronoff, Department of Linguistics, State University of New York at Stony Brook, in deriving the Latin name.

\section{REFERENCES}

1. Aluotto, B. B., R. G. Wittler, C. O. Williams, and J. E. Faber. 1970. Standardized bacteriologic techniques for characterization of Mycoplasma species. Int. J. Syst. Bacteriol. 20:35-58.

1a.Carle, P. Unpublished data.

2. Carle, P., C. Saillard, and J. M. Bové. 1983. DNA extraction and purification. Methods Mycoplasmol. 1:295-299.

3. Carle, P., C. Saillard, and J. M. Bové. 1983. Determination of guanine plus cytosine content of DNA. Methods Mycoplasmol. 1:301-308.

4. Carle, P., F. Laigret, J. G. Tully, and J. M. Bové. 1995. Heterogeneity of genome sizes within the genus Spiroplasma. Int. J. Syst. Bacteriol. 45:178-181.

5. Clark, T. B. 1982. Spiroplasmas: diversity of arthropod reservoirs and hostparasite relationships. Science 212:57-59.

6. Hackett, K. J. 1990. Derrick Edward Award: adaptational biology and spiroplasmas. Zentralbl. Bakteriol. Hyg. Suppl. 20:2-32.

7. Hackett, K. J., and T. B. Clark. 1989. Ecology of spiroplasmas, p. 113-200. In R. F. Whitcomb and J. G. Tully (ed.), The mycoplasmas, vol. 5. Academic Press, San Diego, Calif.

8. Hackett, K. J., R. F. Whitcomb, R. B. Henegar, A. G. Wagner, E. A. Clark, J. G. Tully, F. Green, W. H. McKay, P. Santini, D. L. Rose, J. J. Anderson, and D. E. Lynn. 1990. Mollicute diversity in arthropod hosts. Zentralbl. Bakteriol. Hyg. Suppl. 20:441-454.

9. Hackett, K. J., R. F. Whitcomb, J. G. Tully, J. E. Lloyd, J. J. Anderson, T. B. Clark, R. B. Henegar, D. L. Rose, E. A. Clark, and J. L. Vaughn. 1992 Lampyridae (Coleoptera): a plethora of mollicute associations. Microb. Ecol. 23:181-193.

10. International Committee on Systematic Bacteriology Subcommittee on the Taxonomy of Mollicutes. 1995. Revised minimal standards for descriptions of new species of the class Mollicutes. Int. J. Syst. Bacteriol. 45:605-612.

11. Junca, P., C. Saillard, J. G. Tully, O. Garcia-Jurado, J. R. Degorce-Dumas, C. Mouches, J. C. Vignault, R. Vogel, R. McCoy, R. Whitcomb, D. Williamson, J. Latrille, and J. M. Bové. 1980. Caractérisation de spiroplasmes isolés d'insectes et de fleurs de France continentale, de Corse et du Maroc. Proposition pour une classification des spiroplasmes. C. R. Acad. Sci. Ser. D 290:1209-1212.

12. Konai, M., E. A. Clark, and R. F. Whitcomb. 1992. Temperature ranges growth optima, and growth rates of Spiroplasma (Spiroplasmataceae: class Mollicutes) species. Curr. Microbiol. 32:1-7.

13. Markham, P. G., T. B. Clark, and R. F. Whitcomb. 1983. Culture techniques for spiroplasmas from arthropods. Methods Mycoplasmol. 2:217-223.

14. Rose, D. L., J. G. Tully, J. M. Bové, and R. F. Whitcomb. 1993. A test for measuring growth responses of mollicutes to serum and polyoxyethylene sorbitan. Int. J. Syst. Bacteriol. 43:527-532.

15. Tully, J. G. 1983. Cloning and filtration techniques for mycoplasmas. Methods Mycoplasmol. 1:173-177.

16. Tully, J. G. 1995. Determination of cholesterol and polyoxyethylene growth requirements of mollicutes, p. 381-389. In S. Razin and J. G. Tully (ed.) Molecular and diagnostic procedures in mycoplasmology, vol. 1. Academic Press, San Diego, Calif

17. Tully, J. G., and S. Razin (ed.). 1996. Molecular and diagnostic procedures in mycoplasmology, vol. 2, p. 460-462. Academic Press, San Diego, Calif.

18. Tully, J. G., and R. F. Whitcomb. 1991. The genus Spiroplasma, p. 1960 1980. In A. Balows, H. G. Trüper, M. Dworkin, W. Harder, and K. H. Schleifer (ed.), The prokaryotes, 2nd ed. vol. 2. Springer-Verlag, New York, N.Y.

19. Tully, J. G., J. M. Bové, F. Laigret, and R. F. Whitcomb. 1993. Revised taxonomy of the class Mollicutes: proposed elevation of a monophyletic cluster of arthropod-associated mollicutes to ordinal rank (Entomoplasmatales ord. nov.), with provision for familial rank to separate species with nonhelical morphology (Entomoplasmataceae fam. nov.) from helical species (Spiroplasmataceae), and emended descriptions of the order Mycoplasmatales, family Mycoplasmataceae. Int. J. Syst. Bacteriol. 43:378-385.

20. Tully, J. G., D. L. Rose, E. Clark, P. Carle, J. M. Bové, R. B. Henegar, R. F. Whitcomb, D. E. Colflesh, and D. L. Williamson. 1987. Revised group classification of the genus Spiroplasma (class Mollicutes), with proposed new groups XII to XXIII. Int. J. Syst. Bacteriol. 37:357-364.

21. Whitcomb, R. F. 1983. Culture media for spiroplasmas. Methods Mycoplasmol. 1:147-158.

22. Whitcomb, R. F., and K. J. Hackett. 1996. Identification of spiroplasmas from insects. p. 313-322. In J. G. Tully and S. Razin (ed.), Molecular and diagnostic procedures in mycoplasmology, vol. 2. Academic Press, San Diego, Calif.

23. Whitcomb, R. F., J. G. Tully, D. L. Williamson, J. M. Bové, F. E. French, M Konai, G. Gasparich, M. Abalain-Colloc, C. Saillard, C. Chastel, P. Carle, D. L. Rose, R. Henegar, E. A. Clark, and K. J. Hackett. 1992. Revised classification of spiroplasmas. IOM Lett. 2:134.

24. Williamson, D. L. 1983. Specialized electron microscopic techniques for spiroplasmas in plant and insect tissues. Methods Mycoplasmol. 1:71-76.

25. Williamson, D. L., J. G. Tully, and R. F. Whitcomb. 1979. Serological relationships of spiroplasmas as shown by combined deformation and metabolism inhibition tests. Int. J. Syst. Bacteriol. 29:345-351.

26. Williamson, D. L., J. G. Tully, and R. F. Whitcomb. 1989. The genus Spiro plasma, p. 71-111. In R. F. Whitcomb and J. G. Tully (ed.), The mycoplas mas, vol. 5. Academic Press, San Diego, Calif.

27. Williamson, D. L., R. F. Whitcomb, and J. G. Tully. 1978. The spiroplasma deformation test, a new serological method. Curr. Microbiol. 1:203-207.

28. Williamson, D. L., R. F. Whitcomb, J. G. Tully, G. Gasparich, D. L. Rose, P. Carle, J. M. Bové, K. J. Hackett, R. B. Henegar, M. Konai, C. Chastel, and F. E. French. Revised group classification of the genus Spiroplasma. Submitted for publication. 